\section{Water Quality Changes in Golf Course Irrigation Ponds Transitioning to Reuse Water}

\author{
D.A. Devitt ${ }^{1}$ \\ Department of Natural Resource and Environmental Sciences, University of Nevada \\ Reno, Reno, NV 89557
}

R.L. Morris ${ }^{2}$

University of Nevada Cooperative Extension, 2345 Red Rock Street, Suite 100, Las Vegas, NV, 89146-3160

M. Baghzouz
Department of Biological Sciences, University of Nevada, Las Vegas, NV 89154-4004

M. Lockett ${ }^{3}$

Department of Water Resource Management, University of Nevada, Las, Vegas, NV 89154-4004

\section{L.K. Fenstermaker ${ }^{4}$ \\ Desert Research Institute, 755 East Flamingo Road, Las Vegas, NV 89119}

Additional index words. salinity, nitrogen loading, spectral reflectance, turfgrass, clarity

\begin{abstract}
Irrigation ponds on nine golf courses in southern Nevada were monitored for water quality over a 1600-day period. Three of the golf courses were fresh water courses, three were courses scheduled to transition to reuse water during the study period and three were long term users of reuse water. Salinity [electrical conductivity (EC)], $\mathrm{NO}_{3}^{-}-\mathrm{N}, \mathrm{PO}_{4}^{-} \mathrm{P}, \mathrm{pH}$, algal chlorophyll concentration, clarity, temperature, oxygen, and all major cations and anions were analyzed on a monthly basis. A selected fairway on each course was equipped with water meters to assess irrigation volumes on a bimonthly basis. Estimates of salt and $\mathrm{NO}_{3}^{-}-\mathrm{N}$ loading on fairways were made by weighting irrigation volumes with concentrations of salt (assuming $700 \mathrm{mg} \cdot \mathrm{L}^{-1}$ per $\mathrm{dS} \cdot \mathrm{m}^{-1}$ ) and $\mathrm{NO}_{3}^{-}-\mathrm{N}$ measured in the irrigation ponds. Pond spectral reflectance measurements were obtained on a single monitoring day and correlated with water quality parameters. EC, temperature, $\mathrm{NO}_{3}^{-}-\mathrm{N}, \mathrm{PO}_{4}-\mathrm{P}$, algal chlorophyll concentration and clarity all demonstrated significant changes in all irrigation ponds that transitioned to reuse water $(p<\mathbf{0 . 0 5})$. Multiple regression analysis revealed that as much as $75 \%$ of the variability in $\mathbf{p H}$ in some irrigation ponds could be accounted for based on water quality parameters measured, with higher $\mathrm{R}^{2}$ values associated with elevated $\mathrm{HCO}^{-}$ concentrations. Spectral reflectance (individual wave bands and spectral indices) was shown to be correlated with $\mathrm{pH}$, clarity and algal chlorophyll concentration $\left(R^{2}=0.66^{* *}\right.$ to $\left.0.82^{* * *}\right)$ with a well defined threshold relationship between clarity and the spectral index $R 705 / R 670$. Average yearly $\mathrm{NO}_{3}^{-}-\mathrm{N}$ loads on fairways averaged $8.5 \mathrm{~kg} \cdot \mathrm{ha}^{-1} \cdot \mathrm{yr}^{-1}$ on fresh water courses, $86.5 \mathrm{~kg} \cdot \mathrm{ha}^{-1} \cdot \mathrm{yr}^{-1}$ on transition courses and $209.8 \mathrm{~kg}^{\circ} \mathrm{ha}^{-1} \cdot \mathrm{yr}^{-1}$ on long term reuse courses (all significantly different at $\boldsymbol{p}=\mathbf{0 . 0 5}$ ). Average yearly salt loads on fairways averaged 11,959 $\mathrm{kg} \cdot \mathrm{ha}^{-1} \cdot \mathrm{yr}^{-1}$ on fresh water courses, $14,675 \mathrm{~kg} \cdot \mathrm{ha}^{-1} \cdot \mathrm{yr}^{-1}$ on transition courses and 27,445 $\mathrm{kg} \cdot \mathrm{ha}^{-1} \cdot \mathrm{yr}^{-1}$ on long term reuse courses (long term significantly different at $p=0.05$ ). Such results indicate that significant attention must be given to irrigation strategies used on reuse irrigated golf courses to properly manage for higher nitrogen and salt loads.
\end{abstract}

Population growth in arid southwestern communities in the U.S. coupled with an extended drought has placed increased pressure on avail-

Received for publication 6 May 2005. Accepted for publication 10 July 2005. We thank the Southern Nevada Water Authority and the Las Vegas Valley Water District for financial support of this research project. We also wish to thank Jeff Andersen, Polly Conrad and the many undergraduate students that assisted on the project.

${ }^{1}$ Also with the Office in the Department of Biological Sciences, University of Nevada, Las Vegas NV 891544004. Professor to whom correspondence should be addressed; e-mail dev50@clark.nscee.edu.

${ }^{2}$ Associate professor.

${ }^{3}$ Graduate student.

${ }^{4}$ Assistant research professor. to reuse water discharged in some California (e.g., Whittier) (EC $\left.0.9 \mathrm{dS} \cdot \mathrm{m}^{-1}\right)$.

Using reuse water for irrigation has a long history of success in both rural and urban communities [Kasperson and Kasperson, 1977; U.S. Environmental Protection Agency (USEPA); 1992, U.S. Golf Association (USGA), 1994]. In the urban setting, many communities have irrigated golf courses, street medians, schools and parks with reuse water (Hayes et al., 1990; USEPA, 1992; USGA, 1994). In Las Vegas Valley, which obtains $86 \%$ of its water from the Colorado River, many golf courses are being mandated to switch to reuse water for irrigation purposes(Las Vegas VWD, 2004). In most cases, the current cost of this water has been priced similarly to potable water. Superintendents have voiced concerns over the hidden costs of using reuse water on golf courses; especially the impact it has on mixed landscapes, long term salt balances in soil profiles and the decline in water quality of irrigation ponds and water features (Devitt et al. 2004). In response to these concerns, a five year study was conducted in the Las Vegas Valley, located in Clark County Nevada, to monitor golf courses that eitherirrigated with reuse water, fresh water, or transitioned to reuse water. Results from monitoring the water quality in golf course irrigation ponds and the implications of salt and nitrogen loading on golf course fairways will be discussed.

\section{Materials and Methods}

A reuse study was initiated in 2000 on nine golf courses located in the Las Vegas Valley; three long-term reuse courses (designated as B, $\mathrm{L}$, and W), three fresh water courses (designated as $\mathrm{P}, \mathrm{R}$, and $\mathrm{T}$ ) and three courses identified to transition to reuse water during the monitoring period (designated as A, C, and S). However, because the Colorado River basin is experiencing an extended drought, two of the fresh water courses ( $\mathrm{R}$ and $\mathrm{T}$ ) also transitioned during the latter part of this study. A pond on golf course " $S$ " was designated to become a reuse irrigation pond once transition occurred, however, management decided to maintain it solely as a water feature pond. Reuse water for ponds B and L originated from the City of Henderson Wastewater Treatment Plant, whereas pond W received reuse water that originated from the Clark County Advanced Wastewater Treatment Facility. Two new satellite treatment plants, built in developing areas of the Valley, became available in 2002 (5 and $10 \times 10^{6} \mathrm{gal} / \mathrm{d}$ plants). However, the volume treated and discharged during this study was never great enough to meet irrigation demand except during winter months (A, C, R, S, and T). During spring, summer and fall months all of these irrigation ponds received a blend of reuse water and Colorado River water. Golf course irrigation pond W had been receiving reuse water for $>40$ years. The pond liner was in poor condition allowing shallow saline groundwater to enter and blend with the treated reuse water.

Water quality in irrigation ponds was monitored monthly over a period of $1600 \mathrm{~d}$. Parameters monitored with depth included temperature and oxygen (model 95/50 FT; YSI, 
Yellow Springs, Ohio) and clarity (secchi depth). Parameters monitored at the surface included algal chlorophyll concentration (Moss, 1967), fecal coliform (Elmund et al., 1999), pH (model 500; Microlab), electrical conductivity (Beckman Coulter, Inc., Fullerton, Calif.), $\mathrm{Ca}, \mathrm{Mg}$, Na, K (DX-120 Ion chromatograph, Dionex), $\mathrm{Cl}$ (chloridometer model 425; Haake-Buchler, Saddle Brook, N.J.), $\mathrm{SO}_{4}$ and $\mathrm{PO}_{4}$-P (spectrophotometerUV-120-02 Shimadzu Corp., Kyoto, Japan), $\mathrm{HCO}_{3}^{-}$and $\mathrm{CO}_{3}^{-}$(titration) and $\mathrm{NO}_{3}^{-}-\mathrm{N}$ and $\mathrm{NH}_{4}^{+}-\mathrm{N}(\mathrm{TL}-550 \mathrm{~A}$, Timberline Instruments, Boulder, Colo.).

On 28 May 2002, all previously mentioned water quality parameters were monitored along with spectral reflectance measured at the surface of all nine irrigation ponds using a hand held spectral radiometer (Unispec, PP Systems, Amesbury, Mass.). The Unispec acquires spectra from 400 to $1000 \mathrm{~nm}$ in $3.3 \mathrm{~nm}$ intervals. The resulting data were re-sampled to $1-\mathrm{nm}$ intervals using a software package developed specifically to convert Unispec spectra into 1-nm bands (Multispec, Faiz Rahman, Ball State University, and John Gamon, California State University, Los Angeles). Spectral indices generated included SIPI (structure-insensitive pigment index (R800-R445)/(R800-R680) (Peñuelas et al., 1995), CHL [chlorophyll index (R750-R705)/(R750+R705)], (Gamon and Surfus, 1999; Gitelson and Merzlyak, 1994) and NIR/Red (R705/R670) (Han and Rundquist, 1997).

Water meters were installed on a fairway (hybrid bermudagrass) of each course (irrigation lateral) and monitored bimonthly. Pressure-volume-time curves were established for each fairway allowing meter readings to be converted to precipitation estimates. $\mathrm{NO}_{3}^{-}-\mathrm{N}$ load $\left(\mathrm{kg} \cdot \mathrm{ha}^{-1} \cdot \mathrm{yr}^{-1}\right)$ on each fairway was calculated by weighting monthly irrigation estimates with monthly $\mathrm{NO}_{3}^{-}-\mathrm{N}$ concentrations measured in each pond. Salt load $\left(\mathrm{kg} \cdot \mathrm{ha}^{-1} \cdot \mathrm{yr}^{-1}\right)$ on each fairway was calculated by weighting irrigation estimates with monthly salt content by assuming a conversion of $700 \mathrm{mg} \cdot \mathrm{L}^{-1}$ of salt per $\mathrm{dS} \cdot \mathrm{m}^{-1}$. Average annual potential evapotranspiration (modified Penman combination) in Las Vegas Valley is about $190 \mathrm{~cm}$ and average annual precipitation is about $12 \mathrm{~cm}$.

Data were analyzed using descriptive statistics, analysis of variance (ANOVA) and/or linear and multiple regression analysis. Multiple regressions were performed in a backward stepwise manner, with deletion of terms occurring when $p$ values for the $t$ test exceeded 0.05 .

\section{Results}

General characteristics of all nine irrigation ponds are listed in Table 1. Ponds varied in size from 0.26 to 1.13 ha and in depth from 1.63 to $9.14 \mathrm{~m}$. Five ponds had sulfurburners and fourhad some form of aeration or circulation. Values for water quality parameters $\mathrm{EC}, \mathrm{pH}$, fecal coliform, $\mathrm{NO}_{3}^{-}-\mathrm{N}, \mathrm{PO}_{4}^{-} \mathrm{P}$, and algal chlorophyll concentration are reported over the 1600 -d monitoring period in Figs. 1-6, with separation based on golf courses using reuse water, transition from fresh to reuse water or fresh water.

Electrical conductivity (EC). EC values in

Table 1. Pond characteristics for all nine golf courses in the study.

\begin{tabular}{lccccc}
\hline Course & $\begin{array}{c}\text { Water } \\
\text { quality }\end{array}$ & $\begin{array}{c}\text { Size } \\
(\mathrm{ha})\end{array}$ & $\begin{array}{c}\text { Depth } \\
(\mathrm{m})\end{array}$ & $\begin{array}{c}\text { S } \\
\text { burner }\end{array}$ & $\begin{array}{c}\text { Aeration/ } \\
\text { circulation }\end{array}$ \\
\hline $\mathrm{P}$ & Fresh & 1.04 & 3.63 & No & No \\
$\mathrm{A}$ & Transition & 1.13 & 5.13 & Yes & Yes \\
$\mathrm{T}$ & Transition & 0.75 & 3.50 & Yes & Yes \\
$\mathrm{R}$ & Transition & 0.26 & 9.14 & Yes & Yes \\
$\mathrm{C}$ & Transition & 0.34 & 3.78 & No & Yes \\
S & Transition & 0.42 & 3.00 & Yes & No \\
L & Reuse & 0.31 & 3.13 & No & No \\
B & Reuse & 0.32 & 1.63 & Yes & No \\
W & Reuse & 0.43 & 1.63 & &
\end{tabular}

the fresh water pond and in ponds before reuse transition oscillated around $1.0 \mathrm{dS} \cdot \mathrm{m}^{-1}$. Long term reuse ponds oscillated near $2.0 \mathrm{dS} \cdot \mathrm{m}^{-1}$, with the exception of golf course $\mathrm{W}$ which had the pond liner problem mentioned in the materials and methods section. Figure 7 reveals the inverse relationship between irrigation volumes used on a monthly basis and the measured salinity level for three selected courses. In the case of pond $\mathrm{W}$, irrigation volumes during winter months were low which led to a low turnover rate in the pond. Greater blending of shallow saline groundwater occurred during the winter months resulting in significant EC spikes beyond the baseline EC value for reuse water discharged by the treatment plant (such results were used by the superintendent to convince management that new liners should be installed). This response contrasts with golf courses C and A (Fig. 7). Golf course $C$ revealed a fairly steady EC value that did not oscillate in response to irrigation volume and only increased when transition occurred on day 1308. Golf course A revealed steady EC values until transition occurred on day 534 and then EC oscillated inversely with irrigation volume. This oscillation was driven by the inability of the small satellite treatment plant to meet irrigation requirements during peak environmental demand periods. During winter months golf courses received $100 \%$ reuse water but during other months they received a blended amount. However, average EC values during the transition (blended) months were significantly higher than the EC values measured during the pretransition period $(p<0.05$, Table 2$)$. Only in a few cases didEC values in the transition ponds approach EC values close to those reported for the reuse ponds but all clearly demonstrated a shift once reuse water was being delivered. Irrigation pond $\mathrm{S}$ was used as a water feature and no water was pumped out for irrigation purposes, thus average EC values were the highest of all ponds $\left(2.63 \pm 0.17 \mathrm{dS} \cdot \mathrm{m}^{-1}\right)$, reflecting long term evapo-concentration of salts. Upon transition to reuse water, EC values in pond $\mathrm{S}$ increased above $3.0 \mathrm{dS} \cdot \mathrm{m}^{-1}$.

$p H . \mathrm{pH}$ values in all irrigation ponds oscillated from month to month, with most ponds maintaining values at or above 8.0 (Fig. 2). Pond A was the exception (only pond with 1600 day average below 8.0 at $7.70 \pm 0.57$ ), as the superintendent actively used his sulfur burner during the entire study period. $\mathrm{pH}$ values on the nine ponds were as low as 3.2 and as high as 10.1. Low $\mathrm{pH}$ values were always associated with golf courses that operated sulfur burners and values above 9.0 were always associated with reuse ponds (either long term reuse or after transition). Three of the four transitioning irriga- tion ponds $(\mathrm{C}, \mathrm{R}$, and $\mathrm{T})$ showed a significant rise $(p<0.05$, Table 2$)$ in $\mathrm{pH}$ after switching to reuse water.

Fecal coliform. Fecal coliform in reuse water discharged by the treatment plants always had a 30 -d geometric mean $<2.0$ colony forming units (cfu) $(1.03+0.26)$. However, average fecal coliform measured in the nine irrigation ponds was significantly higher $(p<$ $0.05)$ than the discharge values, with values as high as $800 \mathrm{cfu}$ (pond $\mathrm{C}$ before transition) (Fig. 3). Higher cfu values were typically found in the fresh water ponds $(\mathrm{C}$ and $\mathrm{S}$, average values of 95.1 and $85.3 \mathrm{cfu}$ ), which were always noted to have large avian populations (reuse pond $\mathrm{W}$ also was noted to have a high avian population, $64.8 \mathrm{cfu}$ ). No transitioning irrigation ponds showed a significant rise $(p<$

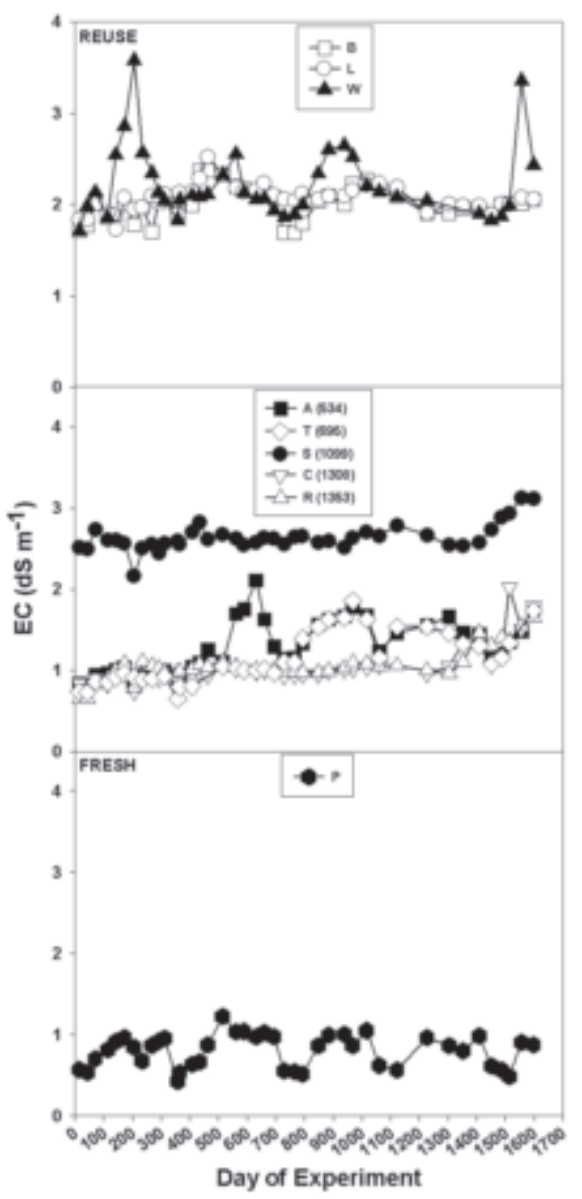

Fig. 1. Electrical conductivity $\left(\mathrm{dS} \cdot \mathrm{m}^{-1}\right)$ in irrigation ponds measured over the 1600-d monitoring period, separated based on fresh water courses $(\mathrm{P})$, transition to reuse courses (A, T, S, C, and R) and long-term reuse courses (B, L, and $\mathrm{W}$ ). 
0.05, Table 2) in fecal coliform after switching to reuse water.

Nitrate-nitrogen. $\mathrm{NO}_{3}{ }^{-} \mathrm{N}$ concentrations (Fig. 4) remained below $3 \mathrm{mg} \cdot \mathrm{L}^{-1}$ in all ponds that contained fresh water (with one exception in pond $\mathrm{R}$ on day 300 ). Whereas $\mathrm{NO}_{3}^{-}-\mathrm{N}$ concentrations in reuse ponds oscillated between 1 and $27 \mathrm{mg} \cdot \mathrm{L}^{-1}$, with most values falling in the range of 8 to $16 \mathrm{mg} \cdot \mathrm{L}^{-1}$. Once irrigation ponds transitioned to reuse water, $\mathrm{NO}_{3}^{-} \mathrm{N}$ concentrations oscillated up and down based on blending rates, with highest concentrations occurring during winter months when $100 \%$ reuse water was delivered to the golf courses. All four transitioning irrigation ponds $(A, C$, $\mathrm{R}$, and $\mathrm{T})$ revealed a significant rise $(p<0.05$, Table 2) in $\mathrm{NO}_{3}{ }^{-}$-N concentration after switching to reuse water.

Phosphate-phosphorus. $\mathrm{PO}_{4}-\mathrm{P}$ concentrations (Fig. 5) remained below $0.5 \mathrm{mg} \cdot \mathrm{L}^{-1}$ in all ponds that contained fresh water. However, in reuse ponds and transitional ponds that contained reuse water, $\mathrm{PO}_{4}-\mathrm{P}$ concentrations oscillated from 0 to $4.2 \mathrm{mg} \cdot \mathrm{L}^{-1}$. Oscillations in reuse ponds were driven by state regulations requiring wastewater treatment plants to reduce $\mathrm{PO}_{4}-\mathrm{P}$ concentrations during summer months. Thus, transitional ponds oscillated because treatment plant managers met state regulations and because of varying blending rates during the year. It was interesting to note the relatively

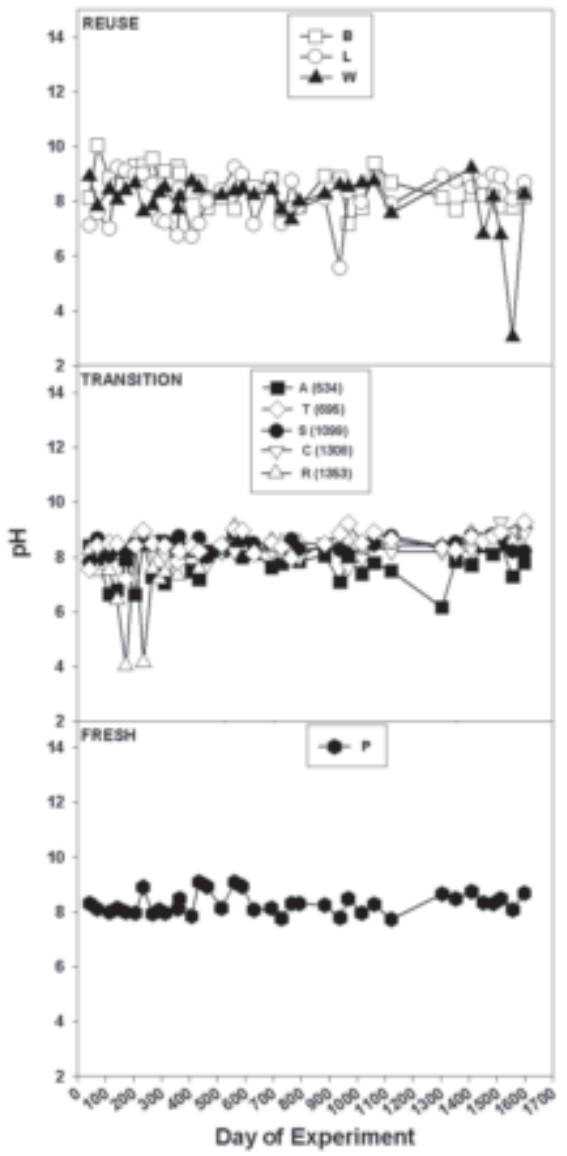

Fig. 2. The $\mathrm{pH}$ in irrigation ponds measured over the 1600-d monitoring period, separated based on fresh water courses $(\mathrm{P})$, transition to reuse courses (A, T, S, C, and R) and long-term reuse courses $(\mathrm{B}, \mathrm{L}$, and $\mathrm{W})$. low concentrations of $\mathrm{PO}_{4}-\mathrm{P}$ in reuse pond $\mathrm{W}$ for the first $300 \mathrm{~d}\left(<0.3 \mathrm{mg} \cdot \mathrm{L}^{-1}\right)$ and then the significant increase in concentration around day 390 (as high as $1.8 \mathrm{mg} \cdot \mathrm{L}^{-1}$ ). This rise in $\mathrm{PO}_{4}-\mathrm{P}$ concentration coincided with the removal of dense aquatic vegetation that dominated the entire irrigation pond. However, by day 420, aquatic vegetation had fully reestablished in the irrigation pond and $\mathrm{PO}_{4}-\mathrm{P}$ concentrations returned to low concentrations not typical of the other reuse ponds. All four transitioning irrigation ponds (A, C, R, and $\mathrm{T}$ ) showed a significant rise in $\mathrm{PO}_{4}-\mathrm{P}$ concentration after switching to reuse water $(p<0.05$, Table 2$)$.

Algal chlorophyll concentration. Algal chlorophyll concentrations (Fig. 6) were extremely low $\left(<25 \mu \mathrm{g} \cdot \mathrm{L}^{-1}\right)$ in the sole long term fresh water irrigation pond $(\mathrm{P})$. However in the reuse and transition ponds, values oscillated up toward $100 \mu \mathrm{g} \cdot \mathrm{L}^{-1}$ and in the case of a few transitional ponds, increased in concentration beyond $200 \mu \mathrm{g} \cdot \mathrm{L}^{-1}$ (A and T). The most dramatic changes over time occurred in the two ponds that had the earliest transition to reuse water (pond A on day 534, and pond T on day 695). Ponds R and C, which had less than a one year transition time revealed algal chlorophyll concentration increases of $110 \%$ and $224 \%$, respectively. Whereas, Ponds $\mathrm{T}$ and $\mathrm{A}$, which had greater than a 2-year transition time (2.47 and 2.92 years, respectively) revealed algal chlorophyll concentration increases of 547

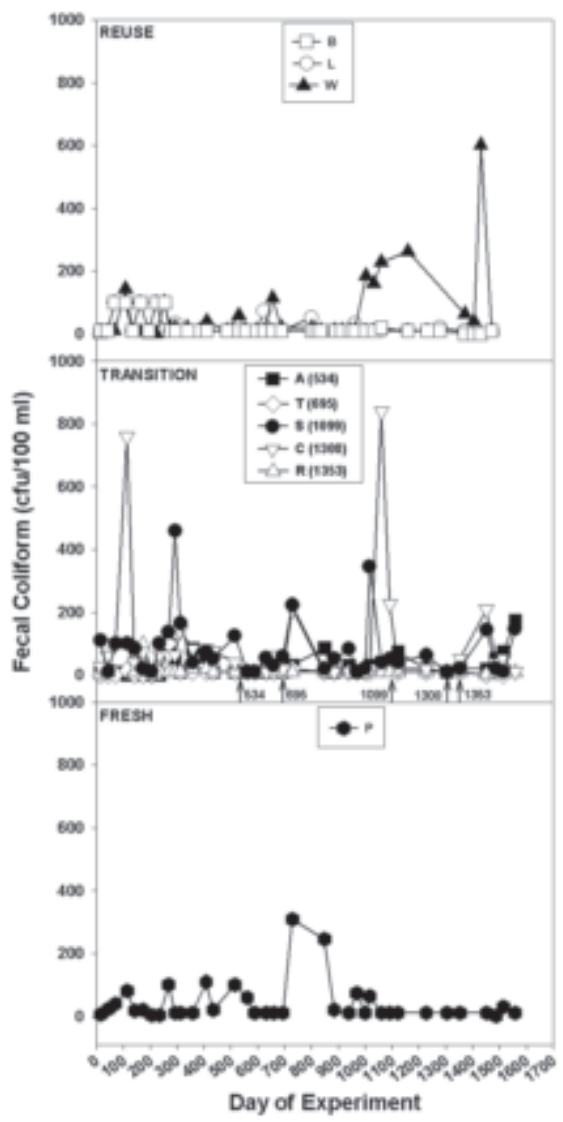

Fig. 3. Fecal coliform (cfu/100 mL) in irrigation ponds measured over the 1600-d monitoring period, separated based on fresh water courses (P), transition to reuse courses (A, T, S, C, and R) and long-term reuse courses (B, L, and $\mathrm{W})$. and $864 \%$, respectively. Time after transition in years accounted for $94 \%$ of the variability in algal chlorophyll concentration when these four transition irrigation ponds were included (pond $\mathrm{S}$ not included because it was not an irrigation pond and because large quantities of colorant were added to this water feature pond).

Factors influencing $\mathrm{pH}$, algal chlorophyll concentration, and clarity (secchi depth). Stepwise regression analysis was used to assess which water quality parameters accounted for the greatest amount of variation in $\mathrm{pH}$, algal chlorophyll concentration and secchi depth measurements. Table 3 reports the parameters selected and the associated $R^{2}$ values (only $R^{2}$ values $>0.35^{* * *}$ are reported). Attempts were made to merge all of the pond data whether it came from reuse ponds, fresh ponds or transitional ponds. However, in all cases, higher $R^{2}$ values were obtained when data sets were confined to each individual irrigation pond. We restricted the number of parameters in the regression equations to four by lowering the accepted $p$ value, thus increasing the sample number to parameter ratio to minimize the chance of cocorrelation. In the case of $\mathrm{pH}, 6$ of the 9 courses had $R^{2}$ values $>0.35^{* * *}$. The three ponds with the highest $R^{2}$ values, all had $\mathrm{HCO}_{3}^{-}$concentration as a significant factor $\left(\mathrm{pH} \uparrow\right.$ as $\mathrm{HCO}_{3}^{-} \uparrow$ ) In fact 4 of the 6 ponds listed in Table 3 included $\mathrm{HCO}_{3}{ }^{-}$concentrations as a key parameter. Only

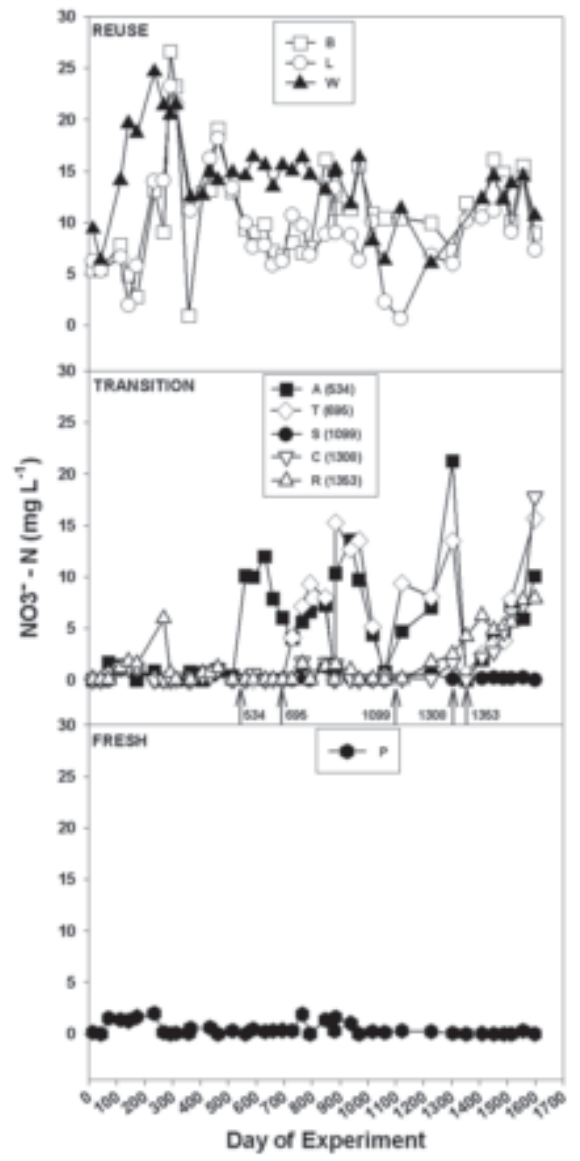

Fig. 4. $\mathrm{NO}_{3}^{-}-\mathrm{N}\left(\mathrm{mg} \cdot \mathrm{L}^{-1}\right)$ in irrigation ponds measured over the 1600-d monitoring period, separated based on fresh water courses $(\mathrm{P})$, transition to reuse courses (A, T, S, C, and R) and long-term reuse courses $(\mathrm{B}, \mathrm{L}$, and $\mathrm{W})$. 
3 irrigation ponds had significant correlations $\left(\mathrm{R}^{2}>0.35^{* * *}\right)$ between water quality parameters and algal chlorophyll concentrations. All three of these irrigation ponds were transitional ponds and no one parameter had commonality between ponds. Clarity measurements (secchi depth) had significant correlations in 4 of the 9 irrigation ponds, with $\mathrm{NO}_{3}^{-}-\mathrm{N}$ being the only parameter selected in more than one regression analysis.

Spectral analysis. Spectral reflectance measurements (individual wavebands and spectral indices) were obtained on a single monitoring day in 2002. Because of the small data set, all data were merged (reuse, fresh and transition ponds) for regression analysis. Spectral signatures for ponds separated based on the presence of either two peaks at about $550 \mathrm{~nm}$ and $705 \mathrm{~nm}$ or the presence of only a single peak at $550 \mathrm{~nm}$ (data not shown). Table 4 reports the selected wavebands or indices that described the variation in $\mathrm{pH}$, secchi depth and algal chlorophyll concentration. In the case of waveband regression analysis for secchi depth and algal chlorophyll concentration, all wave bands were $\log$ transformed. Wavebands at 402 $\mathrm{nm}, 670 \mathrm{~nm}$ and $705 \mathrm{~nm}$ accounted for $82 \%$ of the variation in the algal chlorophyll concentration, whereas the spectral index R705/R670 accounted for only $68 \%$ of the variation in the algal chlorophyll concentration (Table 4). However,

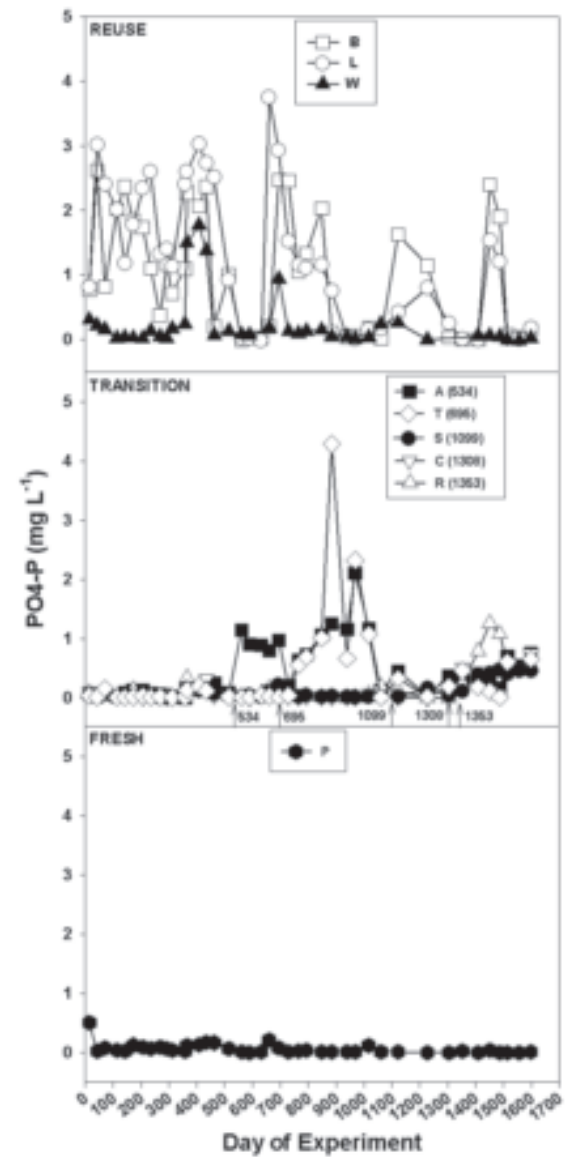

Fig. 5. $\mathrm{PO}_{4}-\mathrm{P}\left(\mathrm{mg} \cdot \mathrm{L}^{-1}\right)$ in irrigation ponds measured over the 1600-d monitoring period, separated based on fresh water courses $(\mathrm{P})$, transition to reuse courses (A, T, S, C, and R) and long-term reuse courses (B, L, and $\mathrm{W})$. the R705/R670 spectral index revealed a two phase linear fit with secchi depth, suggesting a threshold R705/R670 value of about 0.8 (Fig. 8) for the data collected in this experiment. It was interesting to note that irrigation pond $\mathrm{W}$ (long term reuse with heavy aquatic weeds) did not have an elevated 705R/R670 ratio (Fig. 8) and only lost clarity when the aquatic weeds were removed and $\mathrm{PO}_{4}-\mathrm{P}$ concentrations increased.

Nitrate nitrogen and salt load estimates for golf course fairways. Annual $\mathrm{NO}_{3}^{-}-\mathrm{N}$ and salt load estimates for each monitored fairway are reported in Tables 5 and 6 and one site for each treatment (reuse $(\mathrm{L})$, fresh $(\mathrm{P})$ and transition course (T)) was plotted in Fig. 9 for the entire 1600 day monitoring period. Since pond S was not used for irrigation purposes, no load estimates were made for this fairway. $\mathrm{NO}_{3}^{-}-\mathrm{N}$ loads varied from as low as $3.1 \mathrm{~kg} \cdot \mathrm{ha}^{-1} \cdot \mathrm{yr}^{-1}$ on fairway T (2001) irrigated with fresh water to as high as $350 \mathrm{~kg} \cdot \mathrm{ha}^{-1} \cdot \mathrm{yr}^{-1}$ on fairway L irrigated with reuse water (2001). A significant rise in the $\mathrm{NO}_{3}^{-}-\mathrm{N}$ load occurred in all transitional golf courses $(A, C, R$, and $T$ ) once fresh water was replaced with reuse water, such as the 27 fold increase observed on fairway C (2003 vs. 2004, Table 5). However, the highest loadings were always reported on the long term reuse courses (B, L and W), irrigated with $100 \%$ reuse water. Courses that transitioned to reuse water $(\mathrm{A}, \mathrm{C}$, $\mathrm{R}$, and $\mathrm{T}$ ) and received a blended reuse supply

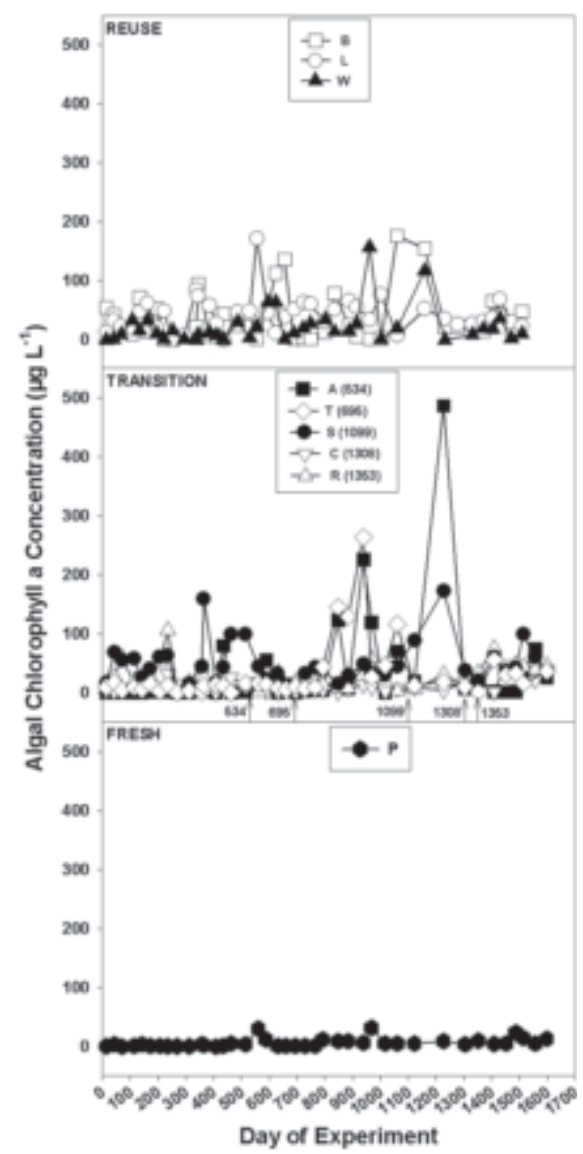

Fig. 6. Algal chlorophyll a concentration $\left(\mu \mathrm{g} \cdot \mathrm{L}^{-1}\right)$ in irrigation ponds measured over the 1600-dmonitoring period, separated based on fresh water courses (P), transition to reuse courses (A, T, S, C, and R) and long-term reuse courses $(\mathrm{B}, \mathrm{L}$, and $\mathrm{W})$. of water that varied throughout the year, never approached the highest $\mathrm{NO}_{3}^{-}-\mathrm{N}$ loads that occurred on the long term reuse courses $(\mathrm{B}, \mathrm{L}$, and W). In fact, the average yearly $\mathrm{NO}_{3}{ }^{-}-\mathrm{N}$ load on the fresh courses (fresh plus fresh ponds before transition) averaged $8.5 \pm 5.3 \mathrm{~kg} \cdot \mathrm{ha}^{-1} \cdot \mathrm{yr}^{-1}$ while the average on transitional courses (blended) averaged $86.5 \pm 29.7 \mathrm{~kg} \cdot \mathrm{ha}^{-1} \cdot \mathrm{yr}^{-1}$. Both of these yearly estimates were significantly less that the $209.8 \pm 78.0 \mathrm{~kg} \cdot \mathrm{ha}^{-1} \cdot \mathrm{yr}^{-1}$ averaged on long term reuse courses (all significantly different from each other at $p=0.05$ )

Salt loads for golf course fairways (Table 6) varied from a low of $3,470 \mathrm{~kg} \cdot \mathrm{ha}^{-1} \cdot \mathrm{yr}^{-1}$ (fresh P) to a high of $35,091 \mathrm{~kg} \cdot \mathrm{ha}^{-1} \cdot \mathrm{yr}^{-1}$ (reuse L). Average yearly salt loads on all fresh courses was 11,959 $\pm 5,520 \mathrm{~kg} \cdot \mathrm{ha}^{-1} \cdot \mathrm{yr}^{-1}$, on transition courses 14,675 $\pm 4,594 \mathrm{~kg} \cdot \mathrm{ha}^{-1} \cdot \mathrm{yr}^{-1}$ compared to $27,445 \pm 5,382$ $\mathrm{kg} \cdot \mathrm{ha}^{-1} \cdot \mathrm{yr}^{-1}$ on long term reuse courses (fresh and transition significantly different from reuse at $p$ $=0.05$ ). Because salt load is dependent on the salt concentration and irrigation volume, high salt loads were reported on some pretransition courses such as course $\mathrm{R}$ because irrigation volumes were over $50 \mathrm{~cm}$ during some summer months while irrigating with Colorado River water $\left(0.9 \mathrm{dS} \cdot \mathrm{m}^{-1}\right)$. This contrasts with reuse course $\mathrm{W}$ that had a lower yearly average salt load $\left(18,303 \mathrm{~kg} \cdot \mathrm{ha}^{-1} \cdot \mathrm{yr}^{-1}\right)$ than pre transition course $\mathrm{R}\left(20,053 \mathrm{~kg} \cdot \mathrm{ha}^{-1} \cdot \mathrm{yr}^{-1}\right)$ even though its irrigation salinity averaged $2.22 \pm 0.40 \mathrm{dS} \cdot \mathrm{m}^{-1}$. This apparent contradiction can be explained by the summer time irrigation volumes that were typically below $25 \mathrm{~cm} \cdot \mathrm{month}^{-1}$ on reuse course W. Thus, most salt load occurred on all nine courses during peak summer months.

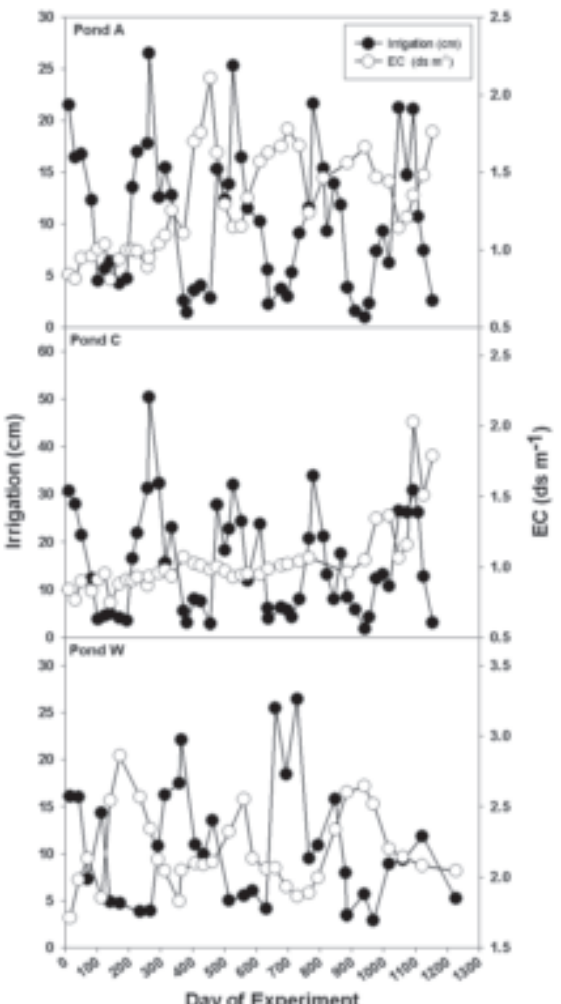

Fig. 7. Irrigation $(\mathrm{cm})$ applied to fairways and electrical conductivity in irrigation ponds $\left(\mathrm{dS} \cdot \mathrm{m}^{-1}\right)$ measured over the 1600-d monitoring period on two transition courses (A and $\mathrm{C}$ ) and one long-term reuse course (W). 
Table 2. Water quality for irrigation ponds (A, C, R, and T) before and after transition to reuse water.

\begin{tabular}{|c|c|c|c|c|c|c|c|c|}
\hline \multirow[b]{2}{*}{ Parameter } & \multicolumn{2}{|c|}{ A } & \multicolumn{2}{|c|}{$\mathrm{C}$} & \multicolumn{2}{|c|}{$\mathrm{R}$} & \multicolumn{2}{|c|}{$\mathrm{T}$} \\
\hline & Before & After & Before & After & Before & After & Before & After \\
\hline$\overline{\mathrm{EC}\left(\mathrm{dS} \cdot \mathrm{m}^{-1}\right)}$ & 0.98 & $1.51^{*}$ & 0.95 & $1.46^{*}$ & 0.99 & $1.41^{*}$ & 0.89 & $1.42^{*}$ \\
\hline $\mathrm{pH}$ & 7.62 & 7.77 & 8.20 & $8.66^{*}$ & 7.86 & $8.73^{*}$ & 8.35 & $8.66^{*}$ \\
\hline Temperature $\left({ }^{\circ} \mathrm{C}\right)$ & 16.26 & $19.35^{*}$ & 16.07 & $21.25^{*}$ & 16.25 & $20.6^{*}$ & 16.70 & $19.90^{*}$ \\
\hline $\mathrm{NO}_{3}^{-}-\mathrm{N}\left(\mathrm{mg} \cdot \mathrm{L}^{-1}\right)$ & 1.06 & $6.90^{*}$ & 0.42 & $5.87^{*}$ & 0.74 & $5.95^{*}$ & 0.46 & $7.57^{*}$ \\
\hline $\mathrm{PO}_{4}^{3}-\mathrm{P}\left(\mathrm{mg} \cdot \mathrm{L}^{-1}\right)$ & 0.09 & $0.71^{*}$ & 0.05 & $0.40^{*}$ & 0.06 & $0.70^{*}$ & 0.04 & $0.73^{*}$ \\
\hline Fecal (cfu) & 24.60 & 36.80 & 98.80 & 72.80 & 19.80 & $10.20^{*}$ & 12.20 & 10.10 \\
\hline Algal chlorophyll $\left(\mu \mathrm{g} \cdot \mathrm{L}^{-1}\right)$ & 5.60 & $54.00^{*}$ & 8.80 & $28.50^{*}$ & 21.90 & $45.8^{*}$ & 8.50 & $55.00^{*}$ \\
\hline $\operatorname{Secchi}(\mathrm{m})$ & 4.32 & $2.03^{*}$ & 2.30 & $1.03^{*}$ & 0.99 & $0.76^{*}$ & 1.87 & $0.92^{*}$ \\
\hline $\mathrm{SAR}_{\mathrm{Adj}}$ & 4.30 & $9.60^{*}$ & 4.87 & $9.07^{*}$ & 4.53 & $8.94^{*}$ & 4.35 & $9.49^{*}$ \\
\hline
\end{tabular}

\section{Discussion}

Based on the results of this study, golf courses that transition to reuse water in developing areas of southern Nevada can expect a delay in maximum salt loads of their irrigation water, since smaller treatment plants (satellite plants) in these areas cannot currently discharge adequate volumes of reuse water to meet $100 \%$ of the irrigation needs during peak demand months. Because these new satellite plants have been designed to bypass early morning salt loads contained in influent associated with residential water softeners (moving on to the main treatment plant), salt loads in reuse water should never be as high as that received on the long term reuse courses receiving reuse water from the main wastewater treatment plants (represented by B, $\mathrm{L}$, and $\mathrm{W}$ ). However, significant changes in all water quality parameters can be expected when substituting reuse water for a potable source. In particular, comparing irrigation ponds $(\mathrm{A}, \mathrm{C}$, $\mathrm{R}$, and $\mathrm{T}$ ) before and after transition, indicated that on average, temperature increased by $25 \%$, clarity decreased by $46 \%$, EC increased by $53 \%$, algal chlorophyll concentration increased by $436 \%, \mathrm{NO}_{3}^{-}-\mathrm{N}$ concentration increased by $1025 \%$ and $\mathrm{PO}_{4}-\mathrm{P}$ concentration increased by $1045 \%$. Such results indicate that with time, a clear decrease in water quality and a decline in aesthetic appearance of irrigation ponds should be expected. Based on the $\mathrm{PO}_{4}-\mathrm{P}$-aquatic weed-clarity response noted on reuse course $\mathrm{W}$, we believe controlling $\mathrm{PO}_{4}$-P concentrations will be essential in maintaining higher aesthetically pleasing irrigation ponds and water features.

The use of spectral reflectance data to predict algal chlorophyll concentrations is well documented (Han and Rundquist, 1997) and in this study a strong threshold relationship was demonstrated between R705/R670 and clarity (secchi depth). It was also shown that the spectral index SIPI was correlated to both $\mathrm{pH}$ and secchi depth (Table 4). Higher SIPI values were associated with higher secchi depth measurements (increased clarity) and lower $\mathrm{pH}$ values. Lower R705/R670 ratios were also associated with lower $\mathrm{pH}$ values $\left(R^{2}=0.78^{* * *}\right)$, suggesting that spectral data could possibly be used in developing a $\mathrm{pH}$ control strategy for improving overall pond clarity.

$\mathrm{NO}_{3}{ }^{-} \mathrm{N}$ and salt loading on golf courses irrigated with reuse water is significant. However, $\mathrm{NO}_{3}^{-}-\mathrm{N}$ loading in most cases is a positive attribute while salt loading is a negative attribute (Harivandi et al., 1992; Marcum and Murdoch, 1990). Applying an average yearly
$\mathrm{NO}_{3}^{-}-\mathrm{N}$ load of $210 \mathrm{~kg} \cdot \mathrm{ha}^{-1} \cdot \mathrm{yr}^{-1}$ with reuse water (maximum value of $350 \mathrm{~kg} \cdot \mathrm{ha}^{-1} \cdot \mathrm{yr}^{-1}$ ), suggests that a significant reduction in fertilizer $\mathrm{N}$ application should occur on reuse courses compared to fresh water courses. Maintaining a $\mathrm{N}$ balance on golf courses will be critical in achieving high color and cover ratings while at the same time reducing the risk of $\mathrm{N}$ becoming an environmental contaminant. Applying an average salt load of $27,445 \mathrm{~kg} \cdot \mathrm{ha}^{-1} \cdot \mathrm{yr}^{-1}$ (maximum value of $35,091 \mathrm{~kg} \cdot \mathrm{ha}^{-1} \cdot \mathrm{yr}^{-1}$ ) on long term reuse courses indicates that it is critical that such courses maintain adequate field-based leaching fractions (Jensen, 1975), high irrigation distribution uniformities (Leskys et al., 1999), and minimize the overhead application of such water to mixed ornamental landscape species (Devitt et al., 2003, 2005; Jordan et al., 2001; Quist et al., 1999). The highest salt loading was associated with salinity sensor values ( 0 to $120 \mathrm{~cm}$ depth) as high as $40 \mathrm{dSm}^{-1}$ (Lockett, personal communication), well in excess of the threshold salinity value reported for bermudagrass (Dean et al.1996)

Based on the work ofDean etal.(1996) it was determined that the I/ET value for bermudagrass-ryegrass should not fall below a threshold value of 0.65 (saline conditions), which would translate into a theoretical leaching fraction of -0.09 . Following the procedures of Jensen (1975), and incorporating the -0.09 value into the predictive equations along with a uniformity coefficient of 0.85 for golf course irrigation systems in southern Nevada (Lockett, unpublished data), a field-based leaching fraction of 0.25 would be predicted. Using this leaching fraction along with an actual ET estimated by Devitt et al. (1992) for bermudagrass/ryegrass (about $150 \mathrm{~cm} \cdot \mathrm{yr}^{-1}$ ) would predict that irrigation volumes should not drop below $2.01 \mathrm{~m} \cdot \mathrm{ha}^{-1} \cdot \mathrm{yr}^{-1}$ to minimize the area receiving the least amount of water. However, because of the extended drought in the Colorado River Basin, water allotments (for the entire golf course) below

Table 3. Multiple regression analysis for $\mathrm{pH}$, secchi depth and algal chlorophyll concentration based on the consideration of all water quality parameters. Arrows indicate increasing $(\uparrow)$ and decreasing $(\downarrow)$ parameter values with increasing values of $\mathrm{pH}$, secchi depth, and algal chlorophyll (Chl) concentration. Only $R^{2}$ values $>0.35$ reported.

\begin{tabular}{|c|c|c|c|}
\hline Course & \multicolumn{2}{|c|}{ Parameter selected } & $R^{2}$ \\
\hline \multicolumn{4}{|l|}{$\overline{\mathrm{pH}}$} \\
\hline W & $\uparrow$ & $\mathrm{HCO}_{3} \uparrow$ & $0.57^{* * * *}$ \\
\hline $\mathrm{R}$ & $\uparrow$ & $\mathrm{HCO}_{3} \uparrow$ Fecal $\downarrow$ & $0.75^{* * *}$ \\
\hline $\mathrm{P}$ & $\uparrow$ & $\mathrm{SO}_{4} \downarrow \mathrm{DO}^{3} \uparrow$ & $0.46^{* * * *}$ \\
\hline $\mathrm{L}$ & $\uparrow$ & $\mathrm{Temp} \downarrow \mathrm{Ca} \downarrow \mathrm{Cl} \downarrow \mathrm{HCO}_{3} \uparrow$ & $0.65^{\text {*** }}$ \\
\hline $\mathrm{A}$ & $\uparrow$ & $\mathrm{Mg} \uparrow \mathrm{HCO}_{3} \uparrow$ & $0.50^{\text {**** }}$ \\
\hline B & $\uparrow$ & $\mathrm{DO} \uparrow \mathrm{PO}_{4} \uparrow$ Fecal $\uparrow$ & $0.54^{* * *}$ \\
\hline \multicolumn{4}{|l|}{ Secchi } \\
\hline A & $\uparrow$ & $\mathrm{NO}_{3} \downarrow$ & $0.38^{* * * *}$ \\
\hline $\mathrm{P}$ & $\uparrow$ & $\mathrm{NO}_{3} \uparrow$ Fecal $\uparrow$ & $0.48^{* * * *}$ \\
\hline $\mathrm{C}$ & $\uparrow$ & Algae $\downarrow$ & $0.40^{* * * *}$ \\
\hline B & $\uparrow$ & $\mathrm{pH} \downarrow$ & $0.37^{* * *}$ \\
\hline \multicolumn{4}{|c|}{ Chl concentration } \\
\hline $\mathrm{T}$ & $\uparrow$ & $\mathrm{Ca} \downarrow \mathrm{Mg} \uparrow$ Fecal $\uparrow$ & $0.64^{* * *}$ \\
\hline $\mathrm{C}$ & $\uparrow$ & $\mathrm{Na} \downarrow \mathrm{K} \uparrow$ & $0.59^{* * * *}$ \\
\hline A & $\uparrow$ & $\mathrm{SO}_{4} \uparrow \mathrm{PO}_{4} \uparrow \mathrm{pH} \downarrow$ & 0.52 \\
\hline
\end{tabular}

Significant at $p<0.001$.

Table 4. Multiple regression analysis for $\mathrm{pH}$, secchi depth, and algalchlorophyll concentration based on consideration of reflectance at wavebands $(\lambda)$ or selected spectral indices.

\begin{tabular}{|c|c|c|c|c|}
\hline Parameter & & & & $R^{2}$ \\
\hline \multicolumn{5}{|l|}{$\overline{\text { Individual } \lambda \text { selected }(\mathrm{nm})}$} \\
\hline $\mathrm{pH}$ & 447 & 550 & 800 & $0.76^{* * *}$ \\
\hline Secchi depth & $706^{\mathrm{z}}$ & $800 Z$ & & $0.81^{* * * *}$ \\
\hline Algal chlorophyll concentration & $402^{z}$ & $670 Z$ & $705^{z}$ & $0.82^{* * * *}$ \\
\hline Spectral index selected & $\mathrm{R} 2$ & & & \\
\hline $\mathrm{pH}$ & SIPI & & & $0.79^{* * *}$ \\
\hline Secchi depth & SIPI & & & $0.66^{* *}$ \\
\hline Algal chlorophyll concentration & R705/R670 & & & $0.68^{* * *}$ \\
\hline
\end{tabular}

${ }^{\mathrm{z}}$ Individual $\lambda \log$ transformed.

******:Significant at $P<0.01$ or 0.001 . 
this threshold value are being recommended. Mandating golf courses to switch to reuse water and then setting water restrictions that may cause them to deficit irrigate (assuming they maintain the same turf grass area) can lead to significant soil profile salinization. Short duration deficit irrigations can be managed but long term deficit irrigations with reuse water with salinity as high as $2.2 \mathrm{dS} \cdot \mathrm{m}^{-1}$ can have a severe impact on growth and overall health of turf grass (Dean et al., 1996; Leskys et al., 1999). Imposing similar water restrictions on fresh and reuse courses assumes that the two waters are of equal substitution value. In the case of Nevada, because of Colorado River return flow credits (Colorado River basin states receive credit for water (such as reuse water) returned to the Colorado river that originated from the Colorado River) the two waters have equal volume substitution value but the impacts on management practices and associated costs to golf courses indicates that they may not truly be equal and should be reevaluated based on water quality and the need to maintain adequate leaching fractions for proper salt balance. An

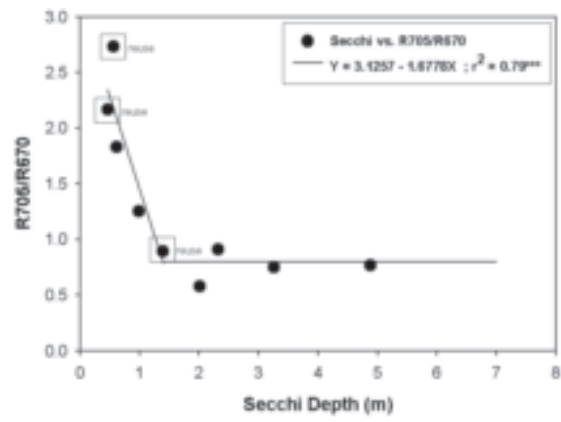

Fig. 8. Spectral index R705/R670 measured on the surface of all nine irrigation ponds on 28 May 2002. Symbols within boxes denote long-term reuse courses. alternative course of action would be to reduce the number of irrigated acres on the golf course, relandscape to lower the total landscape water requirement and/or implement management strategies to reduce water requirements, such as not over seeding, reducing $\mathrm{N}$ fertility and applying growth regulators. Maintaining a welldesigned salinity monitoring program will also

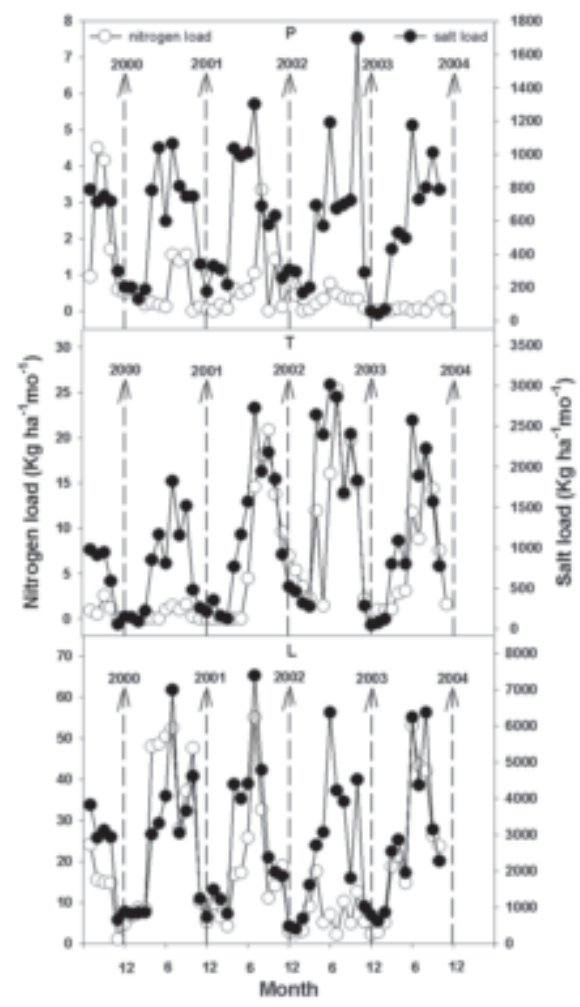

Fig. 9. $\mathrm{NO}_{3}^{-}-\mathrm{N}$ and salt load $\left(\mathrm{kg} \cdot \mathrm{ha}^{-1} \cdot \mathrm{month}^{-1}\right)$ on fairways estimated over the 1600 -d monitoring period for one fresh-water course $(\mathrm{P})$, transition course $(\mathrm{T})$ and long-term reuse course $(\mathrm{L})$.

Table 5. Nitrate-nitrogen load on fairways irrigated with either fresh water, reuse water or a transition from fresh to reuse water.

\begin{tabular}{|c|c|c|c|c|c|c|}
\hline \multirow[b]{2}{*}{ Course } & \multirow{2}{*}{$\begin{array}{l}\text { Water } \\
\text { quality }\end{array}$} & \multirow{2}{*}{$\begin{array}{c}2000 \\
\left(\mathrm{~kg} \cdot \mathrm{ha}^{-1} / 6 \text { months }\right)\end{array}$} & 2001 & 2002 & 2003 & 2004 \\
\hline & & & \multicolumn{4}{|c|}{$\left(\mathrm{kg} \cdot \mathrm{ha}^{-1} \cdot \mathrm{yr}^{-1}\right)$} \\
\hline $\bar{P}$ & Fresh & 12.4 & 6.5 & 8.5 & 3.3 & 0.8 \\
\hline A & Transition & 14.6 & $7.6^{2}$ & 80.0 & 59.3 & 55.3 \\
\hline $\mathrm{T}$ & Transition & 5.9 & 3.1 & $57.6^{\mathrm{z}}$ & 103.3 & 80.5 \\
\hline $\mathrm{R}$ & Transition & 11.3 & 13.5 & 15.5 & 16.0 & $143.7^{z}$ \\
\hline $\mathrm{C}$ & Transition & 15.0 & 10.8 & 12.9 & 3.1 & $83.7^{z}$ \\
\hline $\mathrm{L}$ & Reuse & 74.6 & 349.8 & 213.9 & 80.7 & 250.3 \\
\hline B & Reuse & 152.2 & 294.7 & 191.1 & 189.6 & 215.3 \\
\hline W & Reuse & 81.8 & 201.1 & 231.5 & 90.1 & * \\
\hline
\end{tabular}

${ }^{2}$ Year of transition.

"Estimates not possible due to closure of course for 4-month period.

Table 6. Salt load on fairways irrigated with either fresh water, reuse water or a transition from fresh to reuse water.

\begin{tabular}{|c|c|c|c|c|c|c|}
\hline & Water & 2000 & 2001 & 2002 & 2003 & 2004 \\
\hline Course & quality & $\left(\mathrm{kg} \cdot \mathrm{ha}^{-1} / 6\right.$ months $)$ & \multicolumn{4}{|c|}{$\left(\mathrm{kg} \cdot \mathrm{ha}^{-1} \cdot \mathrm{yr}^{-1}\right)$} \\
\hline$\overline{\mathrm{P}}$ & Fresh & 3470 & 6801 & 7634 & 7242 & 6056 \\
\hline A & Transition & 4853 & $9488^{z}$ & 11783 & 11400 & 9632 \\
\hline $\mathrm{T}$ & Transition & 3622 & 8700 & $14231^{z}$ & 18190 & 11897 \\
\hline $\mathrm{R}$ & Transition & 7058 & 17141 & 22482 & 20535 & $23548^{z}$ \\
\hline $\mathrm{C}$ & Transition & 5910 & 13758 & 12731 & 10937 & $16721^{z}$ \\
\hline $\mathrm{L}$ & Reuse & 14271 & 33049 & 35091 & 31035 & 31138 \\
\hline B & Reuse & 11561 & 27406 & 28345 & 25756 & 22284 \\
\hline W & Reuse & 8917 & 18139 & 22208 & 14563 & * \\
\hline
\end{tabular}

${ }^{\mathrm{z}}$ Year of transition.

"Estimates not possible due to closure of course for 4-month period. be essential for golf courses that transition to reuse water, as salinity must be viewed as a silent threat worthy of our greatest attention.

\section{Literature Cited}

Dean, D.E., D.A. Devitt, L.S. Verchick, and R.L. Morris. 1996. Turfgrass quality, growth and water-use as a function of salinity and water deficit induced stress. Agron. J. 88:844-849

Devitt, D.A., R.L. Morris, and D.C. Bowman. 1992 Evapotranspiration, crop coefficients, and leaching fractions of irrigated desert turfgrass systems. Agron. J. 84:717-723.

Devitt, D.A., R.L. Morris, and D.S. Neumann. 2003. Impact of water treatment on foliar damage of landscape trees sprinkle irrigated with reuse water. J. Environ. Hort. 21:82-88

Devitt, D.A., R.L. Morris, D. Kopec, and M. Henry. 2004. Golfcourse superintendent's attitudes and perceptions toward using reuse water for irrigation in the southwestern United States. HortTechnology 14(4):1-7.

Devitt, D.A., R.L. Morris, and L.K. Fenstermaker. 2005. Foliar damage, spectral reflectance and tissue ion analysis of trees sprinkle irrigated with waters of similar salinity but different chemical composition. HortScience (in press).

Elmund, G.K., M.J. Allen, and E.W. Rice. 1999. Comparison of Escherichia coli, total coliform, and fecal coliform populations as indicators of wastewater treatment efficiency. Water Environ. Res. 71(3):332-339.

Gamon, J.A. and J.S. Surfus. 1999. Assessing leaf pigment content with a reflectometer. New Phytol. 143:105-117.

Gitelson, A.A. and M. Merzlyak. 1994. Spectral reflectance changes associated with autumn senescence of Aesculus hippocastanum and Acerplatanoides leaves. Spectral features and relation to chlorophyll estimation. J. Plant Physiol. 143:286-292.

Han, L.and D.C. Rundquist. 1997. Comparison of NIR/RED ratio and first derivative of reflectance in estimating algal-chlorophyll concentration: A case study in a turbid reservoir. Remote Sens. Environ. 62:253-261.

Harivandi, M.A., J.D. Butler, and L. Wu. 1992. Salinity and turfgrass culture. In: Turfgrass. Agron. Monogr. $32: 207-229$.

Hayes,A.R., C.F.Mancino, and I.L.Pepper. 1990. Irrigation of turfgrass with secondary sewage effluent. I. Soil and leachate water quality. Agron. J. 82:939-943.

Jensen, M.E. 1975. Scientific irrigation scheduling for salinity control of irrigation return flows. U.S. EPA Rpt. 600-2-75-064:1-92. U.S. Govt. Print Office, Wash., D.C.

Jordan,L.A., D.A. Devitt, R.L.Morris, andD.S. Neumann. 2001. Foliar damage to ornamental trees sprinkler-irrigated with reuse water. Irr. Sci. 21:17-25.

Kasperson, R.E. and J.X. Kasperson. 1977. Water reuse and the cities. Univ Press of New England, Lebanon, N.H.

Leskys, A., D.A. Devitt, R.L. Morris, and L.S. Verchick. 1999. Response of tall fescue to saline water as influenced by leaching fractions and irrigation uniformity distributions. Agron. J. 91:409-416.

Las Vegas Valley Water District. 2004. Service rules. Section 2.9. Las Vegas Valley Water District, Las vegas, Nev.

Marcum, K. and C. Murdoch. 1990. Growth responses, ion relations, and osmotic adaptations of eleven $\mathrm{C}_{4}$ turfgrasses to salinity. Agron. J. 82:892-896.

Moss, B. 1967. A note on the estimation of chlorophyll a in freshwater algal communities. Limnology and Oceanography 12:335-340.

Penuelas, J. I. Filella, and J. Gamon. 1995. Assessment of photosynthetic radiation-use efficiency with spectral reflectance. New Phytol. 131:291-296.

Quist, T.M., C.F. Williams, and M.L. Robinson. 1999. Effects of varying water quality on growth and appearance of landscape plants. Journal ofEnvironmental Horticulture 17(2):88-91.

U.S. Environmental Protection Agency. 1992. Guidelines for water reuse. U.S. EPA/625/R-92/004

U.S. Golf Association. 1994. Wastewater reuse for golf course irrigation. Lewis Publ., New York. 